\title{
When Congress Overrules the Court
}

\author{
Abner J. Mikva† \\ Jeff Bleich $\ddagger$
}

\section{INTRODUCTION}

On October 22, 1990, President Bush announced that he would veto the Civil Rights Act of 1990. The announcement met with expected criticism from congressional sponsors of the bill as well as from spokespersons for the civil rights community. While these critics stressed the importance of the legislation for the civil rights movement, the amendments represent another, equally important, legal dimension: a developing institutional conflict between Congress and the Supreme Court. Congress' mitiative im passing the Civil Rights Act did not occur in isolation. Rather, it is but one of several recent attempts by Congress to undo what it deems to be objectionable rulings of the Supreme Court. These efforts by Congress to overrule the Court niay reveal important tensions in the constitutional relationship between these coordinate branches.

Our intention, here, is to understand these recent struggles between Congress and the Court and place them in historical context, relying upon sunilar struggles that occurred at the dawn of the New Deal. There are, of course, inany nistances in which Congress has overruled decisions of the Court, inost of which have innocent, constitutionally unexceptional, explanations. One of the authors served as a law clerk to Justice Minton, when his decision in a contracts case, Wunderlich v. United States, ${ }^{1}$ was overturned by Congress with record-breaking speed. But, as the New Deal era has shown, not all the deeds of the Court and Congress can be innocently explained. There have, for example, been periods of political upheaval or turmoil in which the Court's erroneous interpretations appear to reflect deliberate attempts to frustrate the policy objectives of Congress. Under these circunistances, the dialectic between the

$\dagger$ Chief Judge, United States Court of Appeals for the District of Columbia Circuit. B.A. 1948, Washington University; J.D. 1951, University of Chicago School of Law. The notes accompanying this Article are citations to authority and contain nothing of substance. See Mikva, Goodbye to Footnotes, 56 U. CoLo. L. REv. 647 (1985).

$\ddagger$ Law clerk, Judge Howard M. Holtzmann, U.S.-Iran Claims Tribunal; former law clerk, Chief Justice William H. Rehnquist, United States Supreme Court, and Judge Abner J. Mikva, United States Court of Appeals for the District of Columbia Circuit. B.A. 1983, Amherst College; M.P.P. 1986, Kennedy School of Government, Harvard University; J.D. 1989, Boalt Hall School of Law, University of California, Berkeley. 517, 537).

1. 342 U.S. 98 (1951) (overruled by Act of July 10, 1952, Pub. L. No. 82-488, § 635, 66 Stat. 
Court and Congress has represented not a healthy, respectful effort to clarify their respective obligations and objectives in a particular area, but rather an atteinpt by one brancli to politicize the Constitution in order to accomplish its policy objectives.

We do not suggest that the decisions of the Supreme Court that prompted the recent spate of congressional overrulings were disingenuous or otherwise tainted by policy considerations. The simultaneous rush of bills to overrule Supreme Court decisions could simply be the product of teinporal coincidence or innocent iniscoinmunication between the branclies. Nevertlieless, because of the inanner in whicli the disputed decisions were issued, botli the possibility and the perception exist that the apparent miscommunication between these branclies has been fueled by sharp philosophical differences about the role of the federal government in addressing certain policy matters. Regardless of whether the causes are susceptible of any single explanation, an evaluation of the sinilarity in perception between present circuinstances and those of sixty years ago-the last time tliat Congress was more progressive than the Court-allows us to draw certain general conclusions about the potential costs of the current tensions between the Court and Congress.

Three lessons can be drawn froin the New Deal experience that appear applicable to the present relationship between the Court and Congress. First, when either brancli quibbles with the language of a statute, it risks unsettling its legitimate objectives. When Congress tries to avoid a difficult issue by including vague language, it inay only proinote antagonism and, ultimately, more intense scrutiny of the issue by the Court and the public. Likewise, when the Court quibbles with the language of Congress, it may only entrench contrary congressional opinion and reduce the healthy deference that Congress ought to give to the Court's decisions. Second, parties who seek to win in the Court what they lost in Congress must be wary of what they pray for. Frequently, these parties win the battle but lose the war by galvanizing congressional forces to overrule the Court and advance to an even higler policy ground. Finally, the perception that the Court has been deliberately obstreperous-regardless of whether that perception is accurate-threatens the Court as an institution, by politicizing judicial selection and engendering disrespect for, and relitigation of, its decisions.

\section{The Politics of Overruling}

Congressional overruling of a Supreme Court decision is not a particularly exceptional event. It occurs from time to time when one branch sincerely misunderstands the meaning of, or fails to anticipate, a proper exercise of the other brancli's power. When a statement from Congress is 
unclear, the Supreme Court may mismterpret its meaning, which then requires correction by the Congress. When the Supreme Court is unclear, Congress may feel the need to fill in the imterstices of the Court's opinion to prevent improper interpretation or to undo what it beheves to be an imprudent precedent. As a general proposition, this type of dialectic between the Court and the Congress is valuable even when it creates friction, because it checks errors by the coordinate branches.

Judicial review and congressional overruling are, in the normal course of events, constructive measures to correct the inevitable goofs both branches commit. Members of Congress and Supreme Court Justices are (despite their protests to the contrary) fallible, and sometimes they state propositions more broadly than they had intended. In these circumstances, the natural process of checks and balances provides a quick injection to cure the malady: Congress passes a law to state what it means more precisely.

Unfortunately, the overruling dialogue between Congress and the Court is not always based on such a healthy relationship. Diseased confrontations may occur due to the overreaching of either branch. For example, Congress may attempt to overrule a Supreme Court decision not because the Court has deviated from an acceptable constitutional patl, but because Congress disagrees with the policy results that follow from that constitutional course. The most prominent recent example of this phenomenon is the federal flag burning case.

In Texas v. Johnson, ${ }^{2}$ the Court's construction of the first amendment to the Constitution was consistent with a long hine of precedent, which had protected individuals who put peace sigus on the flag ${ }^{3}$ or wore the flag as a patch on the seat of their pants. ${ }^{4}$ Nevertheless, because Congress disliked the implications of this well-settled constitutional principle, it passed a bill to prohibit flag burning, ${ }^{5}$ essentially thumbing its nose at the Supreme Court's decision. Indeed, the leadership in Congress laad to fight off an effort to overrule the Court by constitutional amendment-a most unusual occurrence in our 200-year history. Such actions by Congress may seem harmless, because most of Congress' chest-beating was not realistically calculated to "overrule" the Constitution. ${ }^{6}$ Yet such congressional behavior produces lastimg mischief by raising doubts about Congress' independent commitment to uphold the Constitution, and by engendering the antagomism of the Court.

2. 491 U.S. 397 (1989).

3. See Spence v. Washington, 418 U.S. 405 (1974) (per curiam).

4. See Smith v. Goguen, 415 U.S. 566 (1974).

5. Flag Protection Act of 1989, Pub. L. No. 101-131, 103 Stat. 77 (codified at 18 U.S.C. $\S 700$ (West Supp. 1990)).

6. Cf. United States v. Eichman, 110 S. Ct. 2404 (1990) (declaring Flag Protection Act of 1989 unconstitutional). 
The stakes are even higher when the Court plays fast and loose with congressional actions. Like members of Congress, Supreme Court Justices are not always immune to the temptation to politicize the Constitution. But unlike members of Congress, only the Justices can reasonably undo precedents that modify constitutional policy. The Court has, arguably, been most susceptible to the urge to substitute its own policy choices during periods in which its political philosophy is diametrically opposed to that of Congress. The most famous example of this occurred early in the New Deal era.

After the conservative-controlled Court invalidated several major pieces of public works legislation, Justice Stone accused the majority of improperly reading imto the Constitution its own "preference for some particular set of economic behefs."7 As a result of the Court's apparent foray into pohicymaking, Congress was forced to concoct elaborate strategies to restore its own valid policies, or to abandon those policies altogether. In those instances where Congress was forced to abandon its policies, the early New Deal Court had not merely ignored an obligation or antagonized a coordinate branch: it had undermined the balance between itself and Congress by confiscating legislative authority and imposing its policy choices mdelibly upon the federal government. The famous "switch in time that saved the Nime"8 ameliorated the tension, but the example continues to be cited as a low-water mark in CourtCongress relations. ${ }^{9}$

Many of the complaints raised during the early New Deal period are being raised today, when, once again, the political composition of one of the branches has diverged from the other. Today, the political views of the Democratic-controlled House and Senate appear to be at odds with the views of a majority of the Supreme Court Justices, five of whom were appointed during the past two Republican administrations. In language remmiscent of Justice Stone's dissent, Justice Marshall recently charged the majority with muposing its own policy views in the field of civil rights by "constitutionalizing its wishful thinking" 10 about race relations, and "launcli[mg] a grapeshot attack on race-conscious remedies" based upon its cymicism over the efficacy of affirmative action. ${ }^{11}$

Because the tensions between Congress and the Court in 1935 and the tensions being expressed today bear some strong resemblances, the

7. Morehead v. New York ex rel. Tipaldo, 298 U.S. 587, 636 (1936) (Stone, J., dissenting).

8. See G. Gunther, Constitutional LAw 466 (11th ed. 1985) (referring to Justice Roberts' votes in majority in Morehead (invalidating state ininimun wage law for woinen) and then in West Coast Hotel v. Parrish, 300 U.S. 379 (1937) (sustaining ininimum wage law for woinen)).

9. See infra Section II(A).

10. City of Richınond v. J.A. Croson Co., 488 U.S. 469, 552-53 (1989) (Marshall, J., dissenting).

11. Id. at 529 . 
following Section examines some of those early New Deal decisions and then compares their reception to that of the Supreme Court's recent civil rights and states' rights decisions. We then draw some conclusions from the two case studies about the present dynamic between the Court and Congress.

II

\section{The New Deal and the Reagan Court}

Although there are many obvious differences between the political climate surrounding the New Deal Court and that surrounding the Reagan Court, there are also certain similarities. The posture of tlie Reagan Court, for example, is dramatically different from that of the New Deal Court. Unlike tlie New Deal Court, which was naturally confronted witli a slew of controversial issues through its direct appeal jurisdiction, the present Court has virtually eliminated that jurisdiction. Moreover, no clear economic or political crises have occurred that required the Court to grant review of a broad set of emergency laws simultaneously.

Nevertheless, the Reagan Court has resembled the New Deal Court in that it has, albeit voluntarily, decided several cases almost simultaneously within a particular policy field. In 1935 and 1936, the New Deal Court invalidated six important pieces of New Deal legislation, all of which liad provided for greater regulation of busmess. ${ }^{12}$ Likewise, in 1989, the Supreme Court narrowed its interpretation of four important civil riglits provisions, all within a six-month period. ${ }^{13}$ By actively taking on related cases in controversial areas, the Reagan Court--like the New Deal Court-has produced a mass of opmions in certain lighly charged political areas in a relatively brief period of time.

Both Courts' actions also received similar receptions from Congress. After the New Deal Court handed down its series of invalidations, the New Deal Congress condemned ${ }^{14}$ what the President called the Court's "reactionary interpretation of the Constitution,"15 and quickly amended several laws to overrule the effects of the Court's decisions. Congress further entertained other bills to alter the composition or jurisdiction of the Court-precipitating a near constitutional crisis. As discussed below, the present Congress' reaction has been remarkably similar: it has passed bills overruling several decisions directly and assumed a highly pohtical posture in confirming judicial nominees.

Thus, both Courts have issued a series of decisions concentrated in a

12. See infra notes $16-32$ and accompanying text.

13. See cases cited infra note 65 .

14. See Mason, Harlan Fiske Stone and FDR's Court Plan, 61 YALE L.J. 791, 791-92 (1952).

15. Stern, The Commerce Clause and the National Economy, 1933-46, 59 HARV. L. REv. 645, 677 (1946) 
narrow policy area that has created a perception of judicial activism and elicited a swift-and critical-response from Congress.

\section{A. The New Deal}

Altliougli the terram of the New Deal lias been picked over by scliolars for years, it is still wortlı revisiting its landmarks in order to understand better the parallels between that period and today. Beginning in 1935 witlı Panama Refining Co. v. Ryan, ${ }^{16}$ the Supreme Court issued a series of six decisions that invahidated key New Deal legislation. Eacli of these decisions appeared to embrace certain laissez-faire principles and states' rights theories that-until that point-most observers had thouglit were on the way out.

In tlie five years preceding Panama Refining, the Court liad taken an increasingly generous view of the legislature's power to regulate the free market. Shortly after Chief Justice Huglies and Justice Roberts were appointed in 1930, for example, the Court uplield a state law forbidding the payment of nonuniform commissions to fire insurance agents. ${ }^{17} \mathrm{Sim}$ ilarly, in State Board of Tax Commissioners v. Jackson ${ }^{18}$ (uploolding a license tax tliat discriminated against cliain stores) and Nebbia v. New York $^{19}$ (upliolding minimum milk prices), tlie Court had demonstrated respect for the economic regulatory powers of tlie states and Congress by relaxing certain preexisting limitations on sucli legislation.

Panama Refining, tlien, represented an abrupt shift backward. Tliat case concerned the application of tlie National Industrial Recovery Act (NIRA), whicl had been tlie centerpiece of President Roosevelt's New Deal. The NIRA souglit to regulate movement of petroleum products by granting the President power to prohibit interstate movement of sucli products beyond those amounts tliat could be produced under state law. The Court lield that this statute unconstitutionally delegated to tlie President legislative power vested in Congress. ${ }^{20}$ Altliougli under thenexisting standards the limits of the President's power were clear enouglı to justify the delegation, tlie Court struck down the Act, instructing Congress that it would need to define sucli delegations witlı greater specificity. Ratlier than quibble witli the Court over the contours of the delegation, the Congress forbade interstate transportation of "hot oil"

16. 293 U.S. 388 (1935).

17. O’Gorman \& Young, Inc. v. Hartford Fire Ins. Co., 282 U.S. 251 (1931); see Hamilton, The Jurist's Art, 31 ColuM. L. REV. 1073, 1073 (1931) (describing Justice Brandeis' O'Gorman decision and views respecting judicial review in general as " 'the opinion of the court,' and a new chapter in judicial history").

18. 283 U.S. 527 (1931).

19. 291 U.S. 502 (1934).

20. Panama Refining, 293 U.S. at 433 (invalidating the NIRA, tit. I, § 9(c), 48 Stat. 195, 200 (1933)). 
altogether, in a bill passed just six weeks later. ${ }^{21}$

Despite Congress' swift overruling, the Court continued with a veritable invalidation spree, striking down several legislative acts, sometimes on grounds that left no room for subsequent legislative cures. In Railroad Retirement Board v. Alton Railroad Co., ${ }^{22}$ the Court struck down a law estabhishing a retirement and pension system for railroad workers, even though it conceded that the workers were engaged in interstate commerce. Soon after, the Court in Carter v. Carter Coal Co. ${ }^{23}$ refused effect to a provision that allowed coal miners and producers to agree upon minimum wages and maximum hours to bind the entire industry.

Congress atteinpted to avoid the Court's harsh decision by regulating through tax incentives, but the Court imvalidated these federal taxes as well, claiming that Congress could not use taxes as a pretext for regulation. In United States v. Butler, ${ }^{24}$ the Court invahdated the Agricultural Adjustment Act, which authorized the Secretary of Agriculture to subsidize farmers who agreed to hmit their production. Likewise, the Court struck down a federal excise tax on sales of liquor prohibited under state law in United States $v$. Constantine, ${ }^{25}$ and a tax deduction for coal producers who adhered to wage and price guidelines. ${ }^{26}$

The Court displayed its restrictive view of the limits on both federal and state authority principally by invalidating several state miminum wage laws. In 1923, the Court had struck down a state minimum wage law in Adkins v. Children's Hospital ${ }^{27}$ on the ground that the law did not factor in either the nature of the work or notions of fair compensation for such work. That decision appeared to have lost most of its vitahity by the time of the New Deal. Specifically, the Adkins rationale seeined to have been eliminated by Nebbia v. New York, ${ }^{28}$ in which the Court, in upholding miminum milk prices, suggested that any statement of general welfare benefit would be sufficient to uphold a pricing constraint. ${ }^{29}$ Nevertheless, New York cautiously atteinpted to coinply with Adkins, passing a law that forbade employers froin hiring women and children at

21. Connally Hot Oil Act, Pub. L. No. 74-14, 49 Stat. 30 (1935) (codified as amended at 15 U.S.C. $\$ 715$ (1988)); see Stern, supra note 15 , at 658 .

22. 295 U.S. 330 (1935) (invalidating the Railroad Retirement Act of 1934, ch. 868, 48 Stat. 1283).

23. 298 U.S. 238, 310-11 (1936) (invalidating the Bituminous Coal Conservation Act of 1935, ch. $824, \S 4$, pt. III(g), 49 Stat. 991,1002$)$.

24. 297 U.S. 1 (1936) (invalidating the Agricultural Adjustment Act of 1933, ch. 25, tit. I, $\S \S 1-21,48$ Stat. $31,31-41)$.

25. 296 U.S. 287 (1935) (invalidating the Revenue Act of 1926, ch. 27, § 701, 44 Stat. 9, 95).

26. Carter Coal, 298 U.S. at 288-89.

27. 261 U.S. 525 (1923).

28. 291 U.S. 502 (1934).

29. Id. at 537 . 
wages that were both less than the fair and reasonable value of the work performed and less than sufficient to meet the minimum cost of living. ${ }^{30}$ Given Nebbia's reasoning, even some of the more jaded observers behieved that such minimum wage laws could withstand constitutional scrutmy. ${ }^{31}$ Thus it came as a surprise when the Court invalidated this new minimum wage law on the ground that all minimum wage laws were unconstitutional. ${ }^{32}$

On occasion, the Court made explicit what was already implicit in these decisions: the Court was motivated by its distaste for a centralized economy as much as by its belief in the constitutional arguments it stated. In Butler, Justice Roberts warned tliat acquiescence to Congress' claimed taxing and spending powers miglit completely undermine tlie system of free enterprise contemplated by the founding fatliers, giving Congress "tlie power to mvade the states' jurisdiction" 33 -by wlicli he seems to liave meant the power to control their economy. ${ }^{34}$ In the notorious "sick chicken" case, Justice Brandeis-normally a dissenter in such cases-joined the majority in order to send a message to the President "tliat we're not going to let this government centralize everytling."35

The Court's economic preferences did not go unnoticed by soine of the Justices. Dissenting in Butler, Justice Stone cliarged that the inajority held the AAA imvalid "not for any want of power in Congress," but because the majority simply disapproved of the legislation. ${ }^{36}$ Justice $^{3}$ Stone privately condenuned this proclivity among his brethren, in one instance accusing tlie Court of constructing a novel "privileges and immunities" argument solely because it wislied to invalidate an econoinic regulation but could not reach the desired result througli an equal protection analysis. ${ }^{37}$ Likewise, Justice Cardozo, dissenting in Panama Refining, complained tliat if economic findings were necessary in order to validate general regulations, "tlie requirement must be looked for elsewhere tlian in the Constitution of the nation."38

30. Morehead v. New York ex rel. Tipaldo, 298 U.S. 587, 605, 621 (1936).

31. See, eg., E. Corwin, The Twilight of the Supreme Court 99-100 (1934).

32. Morehead, 298 U.S. at 610-14 (suggesting that the fault might lie in the illegitimacy of the legislature's goals regardless of the means used to attain them).

33. Butler, 297 U.S. at 78.

34. Cf. United States v. Constantine, 296 U.S. 287, 295-96 (1935) (opinion of Justice Roberts refusing effect to a federal excise tax directed at individuals who sold liquor in violation of state law, because statute invaded state police power).

35. 3 A. Schlesinger, The Age of Roosevelt: The Politics of Upheaval 280 (1960) (referring to Schechter Poultry Corp. v. United States, 295 U.S. 495 (1935)).

36. Butler, 297 U.S. at 79 (Stone, J., dissenting).

37. See A. Mason, Harlan Fiske Stone: Pillar of the Law 399-402 (1956) (discussing Colgate v. Harvey, 296 U.S. 404, 430-31 (1935), which struck down a law creating a preference for local investment on the ground that it interfered with the free right to conduct business across state lines).

38. Panama Refining Co. v. Ryan, 293 U.S. 388, 448 (1935) (Cardozo, J., dissenting). 
The reaction of Congress to the Court's apparent foray into the policymaking forum was swift and predictable. As noted, Congress responded to the Panama Refining decision by banning interstate transportation of hot oil altogether. ${ }^{39}$ Similarly, it revised the federal farm rehief law invalidated in Louisville Joint Stock Land Bank v. Radford ${ }^{40}$ with a few superficial changes sufficient to withstand further constitutional scrutiny. ${ }^{41}$ Congress responded to the minimum wage decisions by passing a law imposing a federal minimum wage law for employees engaged in production of goods for interstate commerce. ${ }^{42}$ The Congress continued to circumvent the Court's rulings by constructing federal taxes to accomplish regulatory purposes. For exainple, it created a federal tax to induce states to provide unemployment insurance, even though it could not itself mandate unemployment insurance. ${ }^{43}$ Likewise, in spite of the hquor tax decision, it did not repeal an almost identical tax on dealers of high-powered firearms, apparently oblivious to - or undeterred by - the Court's decisions. ${ }^{44}$

The rapid response by Congress to cure apparent "defects" in its legislation by any means possible-thereby overruling the Court's decisions-revealed the great antagomism and distrust that pervaded CourtCongress relations. Congress' swift response suggests that it did not believe the Court's decisions represented hard constitutional judgments that required congressional soul-searching, but rather reflected strategic quibbles designed to frustrate congressional pohicy. Contemporaneous observers applauded Congress' uurepentant response, stating that Congress' efforts to repass New Deal legislation was the proper answer to the Supreme Court's "ignominious" disrespect for congressional judgments concerning its own constitutional powers. ${ }^{45}$ These observers complained that the Court's decisions were less deserving of congressional deference because the Court's opinions did not reflect legal conclusions so much as policy opinions in the "field of social and economic legislation." 46

39. See supra text accompanying note 21 .

40. 295 U.S. 555 (1935).

41. Frazier-Lemke Act of 1935, ch. 792, 49 Stat. 943; see Wright v. Vinton Branch, 300 U.S. 440 (1937) (upholding the 1935 bankruptcy legislation, which did not violate the takings clause).

42. Fair Labor Standards Act of 1938,52 Stat. 1060 (current version at 29 U.S.C. $\$ \S 201-219$ (1988)); see United States v. Darby, 312 U.S. 100 (1941) (upholding the legislation as within the comnerce power of Congress).

43. Social Security Act, 49 Stat. 620 (1935) (current version at 42 U.S.C. $\$ 1101$ (1988)); see Steward Mach. Co. v. Davis, 301 U.S. 548 (1937) (upholding the Act).

44. Sonzinski v. United States, 300 U.S. 506, 514 (1937).

45. Brabner-Smith, Congress v. Supreme Court-A Constitutional Amendment?, 22 VA. L. REV. 665, 665 (1936).

46. Id.; see also R. JACKson, The STRuggle for Judicial SupremaCy 175 (1941) (New Deal Conrt "attempted to engraft its own nineteenth century laissez-faire philosophy upon a Constitution intended by its founders to endure for ages"). 
The most dramatic manifestation of the battle between Congress and the Court was the emergence of calls to restrict the powers of the Court, which culminated in President Roosevelt's Court-packing plan. In 1936 and early 1937, several respected legal scholars and legislators recommended a variety of radical constitutional reforms, ${ }^{47}$ including eliminating the Court's power of judicial review, ${ }^{48}$ curtailing the Court's and/or the lower federal courts' appellate jurisdiction, ${ }^{49}$ and even enlarging the meinbership of the Court. ${ }^{\text {so }}$ After several thinly veiled exhortations to Congress to "protect its own prerogatives,"s1 President Roosevelt proposed on February 5, 1937, that the Court be enlarged to fifteen meinbers. The constitutional crisis created by this proposal was averted, however, when two inonths later the Court again abruptly shifted course with a series of cases upholding federal laws, ${ }^{52}$ which defused Court-packing sentiment.

\section{B. The Reagan Court}

The emergence of the Reagan Court in the 1980s was marked by a

47. See generally I. Brant, Storm OVER tHE CONSTITUTION (1936); E. CoRwin, Commerce Power v. States Rights (1936); H. Wallace, Whose Constitution? (1936); Beard, Rendezvous With the Constitution, 88 NEw REPUBLIC 93 (1936); Brabner-Smith, supra note 45, at 671; Collier, The Expanding Meaning of the Constitution, 11 WIS. L. REv. 323 (1936); Dodd, Adjustment of the Constitution to New Needs, 22 A.B.A. J. 126 (1936); Garrison, The Constitution and Social Progress, 10 Tul. L. Rev. 333 (1936); McBain, Some Aspects of Judicial Review, 16 B.U.L. Rev. 525 (1936); Perrigo, Proposals to Restrict Judicial Nullification of Statutes, 8 RockY MTN. L. REV. 161 (1936).

48. Haines, Judicial Review of Acts of Congress and the Need for Constitutional Reform, 45 YALE L.J. 816 (1936); see S.J. Res. 80, 75th Cong., 1st Sess., 81 CONG. REC. 1273 (1937) (Joint Resolution proposing an amendment to the Constitution to provide that any law held unconstitutional by the Supreme Court shall be valid if reenacted by Congress) (Sens. Wheeler and Bone); S.J. Res. 98, 75th Cong., 1st Sess., 81 CoNG. REC. 2691 (1937) (Joint Resolution proposing an amendment to the Constitution relating to the power of the courts to hold laws uneonstitutional) (Sen. Mahoney).

49. Fraenkel, What Can Be Done About the Constitution and the Supreme Court?, 37 Colum. L. Rev. 212, 221-26 (1936); Fraenkel, Constitutional Issues in the Supreme Court, 1935 Term, 85 U. PA. L. REv. 27, 78 (1936); Martig, Congress and the Appellate Jurisdiction of the Supreme Court, 34 MICH. L. REv. 650, 655 (1936).

50. McGovney, Reorganization of the Supreme Court, 25 CALIF. L. REv. 389 (1936); Ratner, Was the Supreme Court Packed by President Grant?, 50 Pol. ScI. Q. 343 (1935).

51. N.Y. Sun, Jan. 4, 1936, § I, at 18, col. 4.

52. See, e.g., West Coast Hotel Co. v. Parrish, 300 U.S. 379 (1937) (upholding federal minimum wage law); NLRB v. Jones \& Laughlin Steel Corp., 301 U.S. 1 (1937) (upholding National Labor Relations Act provisions protecting rights of workers not involved in interstate commeree to organize for purposes of collective bargaining); see also R. MCCLOSKEY, THE AMERICAN SUPREME COURT 175-77 (1960) (discussing the "Constitutional Revolution of 1937"-in which the Court abandoned its anti-New Deal stance-and the failure of the Court-packing plan). See generally $\mathrm{W}$. Leuchtenburg, Franklin D. Roosevelt and the New Deal 231-38 (1963) (discussing the development and ultimate failure of the plan); Leuchtenburg, The Origins of Franklin D. Roosevelt's "Court Packing" Plan, 1966 SUP. Cr. REv. 347 (discussing the political and judicial events that motivated the plan). 
less dramatic, although no less significant, sea change in the political environment than that accompanying the New Deal. Durmg his term in office, President Reagan changed the composition of almost half the Court, appointing Justices O'Connor, Scalia, and Kennedy, and elevating Justice Rehnquist to Chief Justice. In replacing Chief Justice Burger, Justice Powell, and Justice Stewart, the President moved the Court perceptibly toward a more conservative stance. With the appointment of Justice Kennedy, the President obtained, for the first time since World War II, a majority of the Court that shared his political philosophy as to several constitutional issues. In addition, President Reagan appointed a majority of other federal judges, completing a conservative shift $\mathrm{m}$ the federal judiciary at all levels. ${ }^{53}$

In particular, President Reagan's appointees to both the Supreme Court and the lower federal courts tended to share two general philosophical goals. First, these judges tended to display sympathy for the notion of increasing the power of the executive as compared to the legislature, by according deference to administrative agencies and deeinphasizing legislative history to guide agency action. ${ }^{54} \mathrm{~A}$ second feature that characterized the Reagan appointees was an emphasis upon federalist notions of states' riglits and government restraint, reflected by greater reliance upon sovereign immunity and justiciability to bar suits against the states. ${ }^{55}$ President Reagan endorsed this approach of "getting government off the people's backs" by reducing the federal government's oversight of state policymaking and programming. ${ }^{56}$

As miglit be predicted, the post-Reagan judiciary has been marked by greater deference to administrative agencies, a deemphasis of legislative intent, and a skeptical view of federal and private assertions of power over tlie states. $^{57}$ The combination of these judicial tendencies has pro-

53. Wash. Post, Feb. 18, 1991, at A1, col. 2.

54. See Shapiro \& Glicksman, Congress, the Supreme Court, and the Quiet Revolution in Administrative Law, 1988 DukE L.J. 918, 918.

55. Cf. Scalia, The Rule of Law as the Law of Rules, 56 U. CHI. L. REv. 1175, 1179 (1989) (Justice Scalia describes his restrained approach to deciding cases on appeal in order to make as little law as possible).

56. See Mikva, Deregulating Through the Back Door: The Hard Way to Fight a Revolution, 57 U. CHI. L. REv. 521 (1990).

57. See, e.g., Natural Resources Defense Council v. EPA, 902 F.2d 962, 968 (D.C. Cir. 1990); National Fed'n of Fed. Employees v. Cheney, 883 F.2d 1028, 1054 (D.C. Cir. 1990) (Mikva, J., dissenting). For a judicial perspective on these trends, see Easterbrook, The Role of Original Intent in Statutory Construction, 11 HARv. J.L. \& PUB. PoL'Y 59, 65 (1988) (criticizing efforts to divine subjective legislative intent and calling for objective reasonable person standard); Easterbrook, Statutes' Domains, 50 U. CHI. L. REV. 533, 544 (1983) (arguing for limits on judicial power to interpret statutes). See generally Eskridge \& Frickey, Statutory Interpretation as Practical Reasoning, 42 STAN. L. REV 321 (1990) (arguing that practical reasoning, not foundationalism, should guide statutory interpretation); Scalia, supra note 55 (favoring federal deference to state interests). 
duced controversial decisions in several sensitive areas. In two of these areas, Court decisions have roused sufficient controversy to inotivate Congress to inount significant attacks against the decisions directly. Specifically, these involved scrutiny of antidiscrimination provisions and protection of states' rights.

\section{Civil Rights}

The Civil Rights Act of 1990 was drafted in direct response to a flurry of recent Supreine Court opinions, and in the wake of several recent instances in which the Congress overruled Supreme Court decisions narrowing the scope of antidiscrimination remedies. These overrulings provide a useful backdrop for evaluating the Civil Rights Act of 1990.

Between 1982 and 1988, Congress overruled seven Supreme Court decisions concerning interpretation of antidiscrimination provisions; in each instance, Congress mcreased the ability of plaintiffs to bring and prevail in suits compared to the rights recognized by the Court. In 1982, Congress overruled City of Mobile v. Bolden, ${ }^{58}$ which required proof of an intent to discriminate in order to establish a violation of the 1965 Voting Rights Act. ${ }^{59}$ Congress then overruled two 1984 decisions: Smith v. Robinson, ${ }^{60}$ which lield that parents were not cntitled to recover attorney's fees in actions to enforce the Education for All Handicapped Children Act, ${ }^{61}$ and Grove City College v. Bell, ${ }^{62}$ whicl held that title IX's ban on sex discrimination in federally funded schools apphed only to the funded prograins ratlier than to the entire school. Congress also overruled United States Department of Transportation v. Paralyzed Veterans of America, ${ }^{63}$ which held that laws prohibiting discrimination against handicapped persons were inapphicable to coinmercial airlines. Congress has since passed new bills expressly overruling two more decisions that limited access to age-discrimination and disability-discrimmation remedies. ${ }^{64}$

58. 446 U.S. 55 (1980), overruled by Voting Rights Act Amendments of 1982, Pub. L. No. $97-$ 205, 96 Stat. 131 (codified at 42 U.S.C. $\$ 1973$ (1988)).

59. 42 U.S.C. $\$ \S 1971,1973$ to 1973 bb-1 (1988).

60. 468 U.S. 992 (1984), overruled by Handicapped Children's Protection Act of 1986, Pub. L. No. 99-372, 100 Stat. 796 (codified at 20 U.S.C. $\S 1415(\mathrm{e})(4)(B)-(\mathrm{G})(1988)$ ).

61. 20 U.S.C. $\S \S 1400-1407,1411-1426,1431-1436,1441-1444,1451-1454$ (1988).

62. 465 U.S. 555 (1984), overruled by Civil Rights Restoration Act of 1987, Pub. L. No. 100259, 102 Stat. 28 (1987) (codified at 20 U.S.C. $\S \S 1681,1687,1688 ; 29$ U.S.C. $\S \S 706,794 ; 42$ U.S.C. $\S \S 2000 d-4 a, 6107$ (1988)).

63. 477 U.S. 597 (1986), overruled by Air Carrier Access Act of 1986, Pub. L. No. 99-435, 100 Stat. 1080 (codified at 49 U.S.C. app $\S 1374$ (1988)).

64. Education of the Handicapped Act Amendments of 1990, Pub. L. No. 101-476, 104 Stat. 1103 (codified at 20 U.S.C. $\S \S 1400-1485$ (West 1990 \& Supp. 1991)) (overruling Dellmuth v. Muth, 491 U.S. 223 (1989), which held that states were not liable for failure to provide disabled students with federally guaranteed frec, appropriate education); Older Workers Benefit Protection Act, Pub. 
The direct impetus for the Civil Rights Act of 1990, however, came from a series of decisions in 1989. In the first six inonths of that year, the Supreme Court issued four separate decisions in which it interpreted the Constitution and federal statutes in a manner that circumscribed measures established to secure equal treatment under the law. ${ }^{65}$ These decisions narrowed the interpretation of title VII of the Civil Rights Act of 1964 , as well as the equal protection clause of the fourteenth amendment of the Constitution, and the venerable section 1981 of the Civil Rights Act of 1871 .

In the first of these cases, City of Richmond v. J.A. Croson Co., ${ }^{66}$ the Court lield that affirmative action policies were subject to strict scrutiny. Applying that standard, the Court struck down a "set-aside" provision which required that minority contractors receive a fixed percentage of the value of contracts awarded by the city government. ${ }^{67} \mathrm{~A}$ few inontlis later, the Court issued three more decisions in close succession, further limiting race-conscious remedial ineasures. In Wards Cove Packing Co. v. Atonio, ${ }^{68}$ the Court appeared to reverse its long standing interpretation of the burden of proof in title VII cases. The Court held that the employee must always ultimately bear that burden in claims of discrimination-rejecting the notion that the employer must prove a business necessity once a prima facie case is presented. ${ }^{69}$ Likewise, in Martin $v$. Wilks, ${ }^{70}$ the Court expanded the ability of nonparties to challenge affirmative action remedies. The Court permitted white firefighters to contest a negotiated consent decree entered into between black firefighters and the city of Birmingham eiglit years eartier. ${ }^{71}$ Further, in Patterson $v$. McLean Credit Union, ${ }^{72}$ the Court read section 1981 of the Civil Rights Act narrowly, concludimg that the section only prohibited race-based

L. No. 101-433, 104 Stat. 978 (1990) (codified at 29 U.S.C.A. $\$ \S 621,626$ (West Supp. 1990)) (overruling Public Employees Retirement Sys. v. Betts, 109 S. Ct. 2854 (1989), which held that reducing pension benefits unless eligible workers voluntarily retired did not violate federal age discrimination law).

65. Patterson v. McLean Credit Union, 491 U.S. 164 (1989); Lorance v. AT\&T Technologies, 490 U.S. 900 (1989); Martin v. Wilks, 490 U.S. 755 (1989); Wards Cove Packing Co. v. Atonio, 490 U.S. 642 (1989); City of Richmond v. J.A. Croson Co., 488 U.S. 469 (1989); see also Independent Fed'n of Flight Attendants v. Zipes, 491 U.S. 754 (1989) (holding that plaintiffs in title VII suit were not entitled to an award of attorney's fees against a party that intervened to challenge settlement of the suit); Price Waterhouse v. Hopkins, 490 U.S. 228 (1989) (suggesting that an employer who discriminates against an employee may be relieved of liability if it can show that it would have taken the same action absent any discriminatory motive).

66. 488 U.S. 469 (1989).

67. Id. at 486 .

68. 490 U.S. 642 (1989).

69. Id. at $658-60$.

70. 490 U.S. 755 (1989).

71. Id. at 769 .

72. 491 U.S. 164 (1989). 
denials of employment, not demals of promotion..$^{73}$ Finally, in Lorance $v$. $A T \& T$ Technologies, ${ }^{74}$ a less publicized decision, the Court lield that the plaintiffs were time-barred from challenging a discriminatory seniority system, even thougli the system did not affect them until three years later. ${ }^{75}$

Just as the New Deal Congress reacted quickly to the wave of invalidations in the early 1930s, the 101st Congress responded swiftly to the Court's limitation of federal affirmative action measures. The Civil Riglits Act's sponsors openly acknowledged that the amendments were developed in reaction to the Court's affirmative action decisions and were designed not only to overrule the Court, but also to stretcli affirmative action policies still furtlier. ${ }^{76}$

The bill, ${ }^{77}$ whicl passed botl1 houses of Congress but was vetoed by President Busl1, would liave overruled Wards Cove by allowing plaintiffs to carry their burden of proof by offering precisely the type of evidence that was deemed insufficient by the Court. Plaintiffs could prove employment discrimination by establishing a statistically significant disparity and a group of "employment practices" tliat may have resulted in this discrepancy, witlout identifying which specific practice caused which portion of the discrepancy. A second provision would have reversed the Court's decision im Martin v. Wilks. Tliat provision would prevent employees who liad had an opportunity to object to a consent decree during its adoption from cliallenging that decree later, unless they souglit review on belialf of the parties to the decree. Finally, the proposed amendments wonld liave reversed Patterson by expressly incorporating into title VII protection against discrimination in promotion decisions as well as hiring decisions.

The Civil Riglits Act of 1990 did not stop there; it went beyond the Court's rulings and developed a inomentum of its own. The Act, for the first time, would liave allowed victims of sexual, religious, or etlinic discrimination on the job to sue for compensatory and punitive damages under title VII. This provision, as well as several otleers, ${ }^{78}$ would thus have imcreased the number and scope of race-conscious remedies available to civil rights plamtiffs. The parallel to the "lot oil" case is clear:

73. Id. at $\mathbf{1 7 6 - 7 7 .}$

74. 490 U.S. 900 (1989).

75. Id. at 913 .

76. A Bipartisan Hill Coalition Unveils Rights Measure, CoNG. Q., Feb. 10, 1990, at 392; see also Legal Times, June 11, 1990, at 2 (Act ostensibly crafted to reverse Supreme Court decisions, but many believe it does far more than return the law to the status quo ante).

77. S. 2104, 101st Cong., 2d Sess., 136 CoNG. REc. S1018 (daily ed. Feb. 7, 1990).

78. 136 Cong. REC. S9809, S9810 (daily ed. July 10, 1990) (Statement of Sen. Kennedy); see also President's Message to the Senate Returning Without Approval the Civil Rights Act of 1990, 26 WEEKLY COMP. PRES. Doc. 1632 (Oct. 20, 1990) (explaining his veto of the bill). 
where Congress does not feel the Court has treated its enactments with proper sensitivity, it can-and likely will-write those enactments more broadly the second time around.

\section{Sovereign Immunity}

The Court also acted aggressively in deciding cases involving state claims of immunity which narrowed the reach of federal laws. In Atascadero State Hospital v. Scanlon, ${ }^{79}$ the Court found that a state had eleventh amendinent immunity from suit under the federal Rehabilitation Act, absent a direct, unambiguous statement by Congress or the state that it wished to abrogate such immumity by accepting federal funding. ${ }^{80}$ The Court, in this decision, overruled a twenty-year-old precedent ${ }^{81}$ in holding that the Court would never imply abrogation of sovereign immunity even if doing so were crucial to accomphishing Congress' policy objectives. The Court instead announced that it would always require the Congress to state exphicitly when and how it wished its statutes to create actions against the states.

Once again, Congress reacted swiftly to this pronouncement, overruling the Court's decision that barred actions against the states. Congress amended the Rehabilitation Act expressly to reınove immunity and impose monetary habilities upon state and local governments, thereby allowing precisely the type of action held barred by Atascadero. ${ }^{82}$ But, as was the case in the affirmative action decisions, Congress went even further, making states liable for discrimination in prograns for which they receive federal financial assistance. ${ }^{83}$ Apparently in response to Atascadero, Congress enacted another bill directly abrogating state sovereign immunity in the Superfund context, exposing states to private suits for reimbursement of hazardous waste cleanup. ${ }^{84}$

In sum, Congress' response to recent decisions of the Court is strikingly remimiscent of that sounded by the New Deal Congress. Law review articles im the 1930s discussed the "presently smoldering hostility between the legislative and the judicial branches of our National Government"85 and legislators condemned the Court for giving "unnatu-

79. 473 U.S. 234 (1985).

80. Id. at $242-43$.

81. Id. at 258 (Brennan, J., dissenting). But see id. at 243, n.3 (disputing Justice Brennan's assertion).

82. Rehabilitation Act Amendments of 1986, Pub. L. No. 99-506, $\S 1003,100$ Stat. 1807, 1845 (1986) (codified at 42 U.S.C. $\S 2000$ d-7 (1988)) (nnaking states liable for discrimination in certain federally assisted enterprises).

83. Id.

84. Superfund Amendments and Reauthorization Act of 1986, Pub. L. No. 99-499, $\S 101(b)(1), 100$ Stat. 1613,1615 (1986) (codified at 42 U.S.C. $\S 9601(20)(D)$ (1988)) (exposing states to private suits to recover costs of hazardous waste cleanup).

85. See, e.g., Brabner-Smith, supra note 45 , at 665. 
ral and illogical definitions to terms employed by the Congress in enacting legislation" 86 and "substitut[ing] their "own political predilections' for the Constitution of the country."87 Today the language is almost the same. In recent law review articles, the affirmative action decisions were described as a "move backward on the issue of race"88 and a capitulation to a conservative pohitical backlash. ${ }^{89}$ Likewise, one legislator lambasted the Court for its "abrupt and troubling departure" from prior precedents, as it rendered decisions directly at odds with the purposes of title VII. ${ }^{90}$

The Justices theinselves complain of this "hostile" relationship between the Court and the Congress, and the dissenters accuse the majority of unprecedented scrutiny in evaluating certain types of legislation and challenges. Justices Brennan, Marshall, and Stevens, in separate opinions, have criticized the Court's interpretation of civil rights statutes as "needlessly cramped," "pinched," "parsimonious," "formalistic,"91 "severe,"92 and "blimd . . . to the meaning and purpose of Title VII."93 These statements are reminiscent of the salvos launched by Justices Stone, Brandeis, and Cardozo nearly sixty years ago.

\section{III}

\section{What Is THE Fallout?}

It is unlikely that the criticisms currently being leveled at the Supreme Court will produce the same degree of constitutional tension that arose at the inception of the New Deal. First, there are critical differences in the cliniate of the day and the nature of the decisions. The cases that the New Deal Court addressed concerned issues essential to the daily functioning of the government and, accordingly, they demanded an urgent response from Congress. By contrast, many of the issues decided by the present Court do not bear upon the government's functioning or the country's economy as much as they do the vindication of certain rights by a small class of individuals. Thus, it is unlikely that

86. 89 CONG. REC. 6793 (1937) (statement of Sen. Robinson).

87. 89 CoNG. Rec. 6873 (1937) (statement of Sen. Guffey).

88. Blum, Section 1981 Revisited: Looking Beyond Runyon and Patterson, 32 How. L.J. 1, 37 (1989).

89. See Crenshaw, Race, Reform, and Retrenchment: Transformation and Legitimation in Antidiscrimination Law, 101 HARv. L. REv. 1331, 1348 \& n.67 (1988); Coyle, Reagan Legacy Is Alive and Well at High Court, Nat'l L.J., Feb. 6, 1989, at 5, col. 1; Krauthammer, Exit Affirmative Action, Wash. Post, Feb. 3, 1989, at A25, col. 5.

90. 136 CONG. REC. S9390, \$9323 (daily ed. July 10, 1990) (statement of Sen. Kennedy); see also Nomination of William Lucas: Hearings Before the Senate Comm. on the Judiciary, 101st Cong., 1st Sess. (July 1989) (statements of Sens. Simon, Specter, and Biden).

91. Patterson v. McLean Credit Union, 491 U.S. 164, 189 (1989) (Brennan, J., dissenting).

92. Lorance v. AT\&T Technologies, 490 U.S. 900, 914 (1989) (Marshall, J., dissenting).

93. Wards Cove Packing Co. v. Atonio, 490 U.S. 642, 663 (1989) (Stevens, J., dissenting). 
the current pattern of decisions will press the Congress to another constitutional showdown in which it begins to rethink the jurisdiction, selection, or numerical composition of the Court.

Having said this, we would be wrong to conclude that the lessons of the New Deal are without currency. Many of the perceptions that were once held about the New Deal Court are held today about the Supreme Court. Regardless of whether one beheves that the Court's civil rights decisions were animated by a desire to interfere with policy results or are simply the product of strictly applying certain canons of construction, the perception of hostility exists, and it is likely to produce-in one way or another-soine of the consequences that arose at the dawn of the New Deal.

The civil rights decisions, though rooted in constitutional soil, nevertheless produce policy-tainted fruits, and the Court cannot be held blameless for this. The Court contributed to the perception of activism by agreeing to decide so many questions concerning that policy area within a relatively brief period of time, and in particular by abandoning the Court's general policy against revisiting its statutory precedents. ${ }^{94}$

The Court's opinions, to their credit, could be construed as merely demanding more careful draftsmanship from Congress. However, the perception that the Court has been quibbling with Congress' direction is fueled by the fact that none of these cases involved an overly expansive reading by the Court; instead, in each case, the Court took the stingier view of the availability of race-conscious remedies. The perception is cliarged further by the fact that most of the areas in which Congress has overruled the Court involved a substantively progressive policy areafederal environmental protection, civil rights, and capital punishmentapart from the legal issues presented in the case. This does not mean, of course, that the Court's decisions reflect a particular policy agenda, but because they create that perception, they liave produced much of the same mischief created by the New Deal Court.

Three conclusions emerge from the New Deal experience and the present perception of Court/Congress antagomism. First, when either branch quibbles with the language of a statute, it ultimately frustrates the legitimate objectives of both branches. Second, parties who seek to test the vitality of Congress' work in the Court may succeed only in driving the wedge inore deeply between the two branches. Finally, a deliberately obstreperous Court may, if pushed too far, threaten its own stature as an institution by politicizing judicial selection and engendering constant relitigation of its decisions.

94. See Eskridge, Overruling Statutory Precedents, 76 GEo. L.J. 1361 (1988). 


\section{A. Frustrating Legitimate Objectives}

Little good can ever come from open antagonism between the Court and Congress or distrust of one another's conduct. When Congress believes the Court is needlessly obstructing legislative policy, it tends to harden and liarshen its position unnaturally. For example, in the "hot oil" cases, ${ }^{95}$ Congress moved from a judicious restriction on interstate hot oil sales to an absolute ban, im response to the Court's meddling. Likewise, in the sovereign immumity context of current vintage, ${ }^{96}$ Congress not only abrogated the narrow state privilege being asserted but greatly expanded the scope of that abrogation. An angry or frustrated Congress is not Congress at its most considered, deliberative best. Rather than producing the narrow restrictions it desires, the Court may only pusli Congress to adopt sweeping changes.

Likewise, when Congress attempts to shift the political heat to the Court by dehiberately avoiding difficult pohtical questions, it may only intensify the heat it receives later and singe the delicate relationsliip with the Court. Members of Congress who thought they could avoid difficult choices through loose language in the NIRA were forced to face those same or more difficult choices later in a more rarefied and politically charged form. Likewise, in preparing to hear Patterson, ${ }^{97}$ the Supreine Court apparently touched a political nerve when it requested that the parties brief for reconsideration the decision in Runyon v. McCrary. ${ }^{98}$ In response, Congress filed an amicus brief sigued by 66 Senators and 118 Representatives urging the Court to reaffirm its Runyon holding. The brief stated candidly that the members of Congress wished to avoid the political heat of having to decide Runyon itself. Their brief stated that "the legislative effort necessary to restore [Runyon] would likely be fractious and divisive, since corrective legislation would, in all likeliliood, compel the Congress to address numerous periplieral questions concerning the scope and application of Section 1981."99

Thus, to the extent thiat Congress is deliberately opaque or the Court is deliberately obstinate, both create the wrong environment for the Congress properly to decide difficult political issues.

\section{B. Litigation/Lobbying Strategies}

A second general proposition is that individuals who seek to gain from the Court the relief they could not obtain froin Congress frequently

95. See supra text accompanying notes 20-21.

96. See supra text accompanying notes 79-84.

97. Patterson v. McLean Credit Union, 491 U.S. 164, 171 (1989).

98. 427 U.S. 160 (1976).

99. Brief of Amici Curiae in Support of Petitioner at 2, Patterson, 491 U.S. 164 (1989) (No. 87. 107). 
win the battle but lose the war. The litigants who challenged the New Deal Acts succeeded only in driving out the sympathetic judges and entrenching Congress' commitment to the New Deal program. Likewise, as soine form of a Civil Rights Act nears enactinent, the Supreme Court's decisions seem to have produced a conservative defeat. Narrow civil rights decisions prompted Washington lobbyists to assemble an aggressive cainpaign, which may have encouraged Congress to include stronger, less ambiguous language than the political process normally tolerates. At the inception of the effort, lobbyists maintained that any new legislation " 'must be crystal clear'.. . because 'this court seems to be willing to restrict the coverage of civil rights laws whenever and wherever possible." "100 As a result, the new legislation does not merely preserve the status quo: it breaks new ground for civil rights.

In their defense, it is hard to know whether the challengers in the affirmative action cases were trying to frustrate civil rights purposes, or were simply forcing the Court and Congress to define better a comphcated matter that pressed up against certain constitutionally protected rights. If their objective was the latter, then they succeeded admirably. But litigants who hoped to obtain in Court what they lost in Congress may now rue their efforts.

\section{Institutional Authority}

Finally, by not being sensitive to the perception that the Court was actively atteinpting to frustrate Congress' policy agenda, the Court has exposed itself to attack as an institution. The recent series of rulings is likely to pohticize more than ever the congressional scrutiny of nominees for the next vacancy. Judge Bork's experience in attempting to pass the confirmation gauntlet demonstrates that when members of Congress are concerned about faithfulness to their enactinents, they will assume the worst about nommees who do not share their political views.

Congress and the public are also more hikely to assume that decisions are policy-tainted, even when innocently inade. A decision that sinacks of policyinaking taints the legitimacy of all Court rulings. A bad decision makes it easy to discredit the value of the Court's holdings. As Abraham Lincoln pointed out in discussing the Dred Scott ${ }^{101}$ decision: "If this important decision had been made by the unanimous concurrence of the judges and without any apparent partisan bias ... it then ... would be, factious, nay, even revolutionary, not to acquiesce in it as a precedent. But when, as is true, we find it wanting in all these claims to the public confidence, it is not resistance, it is not factious, it is not even

100. Rights Groups Plan Hill Counterattack, Wash. Post, June 17, 1989, at A4, col. 1 (quoting Kerry Scanlon, attorney for the Washington Lawyers Committee for Civil Rights Under Law).

101. Dred Scott v. Sandford, 60 U.S. (19 How.) 393 (1857). 
disrespectful, to treat it as not having yet quite established a settled doctrine for the country." 102

There is already some evidence that Congress has been less restrained in overruling the pronouncernents of the Court. Between 1982 and 1986, Congress overruled at least twenty-three Supreme Court decisions-half within two years of the date of the decision. ${ }^{103}$ These enactments cover a wide range of decisions. For example, in tliree separate instances, Congress directly overruled Court decisions concerning state and local liability under federal acts. ${ }^{104}$ In addition, Congress has either passed or is presently considering five bills overruling Court decisions tliat ease limitations on prosecutions and sentencing. ${ }^{105}$ In all, Congress

102. 2 The Collected Works of Abraham Lincoln, 1848-1858, at 401 (R. Basler ed. 1953).

103. INS v. Phinpathya, 464 U.S. 183 (1984), overruled by Immigration Reform and Control Act of 1986, Pub. L. No. 99-603, § 315(b), 100 Stat. 3359, 3439-40; Block v. North Dakota, 461 U.S. 273 (1983), overruled by Act of Nov. 4, 1986, Pub. L. No. 99-598, 100 Stat. 3351; United States v. New York Tel. Co., 434 U.S. 159, 166-68 (1977), overruled by Electronic Communications Privacy Act of 1986, Pub. L. No. 99-508, § 301, 100 Stat. 1848, 1868-72; Atascadero Statc Hosp. v. Scanlon, 473 U.S. 234 (1985), overruled by Rehabilitation Act Amendments of 1986, Pub. L. No. 99-506, $\S 1003,100$ Stat. 1807, 1845; Smith v. Robinson, 468 U.S. 992 (1984), overruled by Handicapped Children's Protection Act of 1986, Pub. L. No. 99-372, 100 Stat. 796; Lambert Run Coal Co. v. Baltimore \& O.R.R., 258 U.S. 377 (1922), overruled by Judicial Improvements Act of 1985, Pub. L. No. 99-336, § 3, 100 Stat. 633, 637 (1986); California v. Nevada, 447 U.S. 125 (1980), overruled by Act of Dec. 23, 1985, Pub. L. No. 99-200, 99 Stat. 1663; Deepsouth Packing Co. v. Laitram Corp., 406 U.S. 518 (1972), overruled by Patent Law Amendments Act of 1984, Pub. L. No. 98-622, 98 Stat. 3383; Community Communications Co. v. City of Boulder, 455 U.S. 40 (1982), and City of Lafayette v. Louisiana Power \& Light Co., 435 U.S. 389 (1978), overruled by Act of Oct. 24, 1984, Pub. L. No. 98-544, 98 Stat. 2750; Busic v. United States, 446 U.S. 398 (1980), and Simpson v. United States, 435 U.S. 6 (1978), overruled by Department of Interior and Related Agencies Appropriations Act, Pub. L. No. 98-473, $\S 1004$, 98 Stat. 1837, 2138-39 (1984); Washington Metro. Area Transit Auth. v. Johnson, 467 U.S. 925 (1984), overruled by Longshore and Harbor Workers' Compensation Act Amendments of 1984, Pub. L. No. 98-426, § 4, 98 Stat. 1639, 1641; Diedrich v. Commissioner, 457 U.S. 191 (1982), overruled by Deficit Reduction Act of 1984, Pub. L. No. 98-369, $\S 1026,98$ Stat. 494, 1031; United States v. Davis, 370 U.S. 65 (1962), overruled by Deficit Reduction Act of 1984, Pub. L. No. 98-369, § 421, 98 Stat. 494, 793-95; Commissioner v. Standard Life \& Accident Ins. Co., 433 U.S. 148 (1977), overruled by Deficit Reduction Act of 1984, Pub. L. No. 98-369, § 211(a), 98 Stat. 494, 740-41; NLRB v. Bildisco \& Bildisco, 465 U.S. 513 (1984), overruled by Bankruptcy Amendments and Federal Judgeship Act of 1984, Pub. L. No. 98-353, $\S 541,98$ Stat. 333, 390-91; Federal Maritime Comm'n v. Aktiebolaget Svenska Amerika Linien, 390 U.S. 238 (1968), overruled by Shipping Act of 1984, Pub. L. No. 98-237, § 7, 98 Stat. 67, 73-74; Rowan Cos. v. United States, 452 U.S. 247 (1981), overruled by Social Security Amendments of 1983, Pub. L. No. 98-21, § 327, 97 Stat. 65, 126-27; Standard Oil Co. of Cal. v. Agsalud, 454 U.S. 801 (1981), overruled by Act of Jan. 14, 1983, Pub. L. No. 97-473, § 301, 96 Stat. 2605, 2611-12; Pfizer, Inc. v. Government of India, 434 U.S. 308 (1978), overruled by Act of Dec. 29, 1982, Pub. L. No. 97-393, 96 Stat. 1964; McCarty v. McCarty, 453 U.S. 210 (1981), overruled by Department of Defense Authorization Act, Pub. L. No. 97-252, § 1002, 96 Stat. 718, 730-35 (1982); City of Mobilc v. Bolden, 446 U.S. 55 (1980), overruled by Voting Rights Act Amendments of 1982, Pub. L. No. 97 205, \& 3, 96 Stat. 131, 134.

104. See Garcia v. San Antonio Metro. Transit Auth., 469 U.S. 528 (1985); Community Communications Co. v. City of Boulder, 455 U.S. 40 (1982); City of Lafayette v. Louisiana Power \& Light Co., 435 U.S. 389 (1978).

105. See H.R. 5269, 101st Cong., 2d Sess. (1990) (Racial Justice Act); 136 CoNG. REc. H9001, 
overruled more than twice as many decisions in the first four years after President Reagan's first appointment to the Supreme Court than in the entire decade preceding his election. ${ }^{106}$ Although there has been no suggestion that the Court's rulings in all these cases were pohtically motivated, the accelerated pace of overrulings inay reflect a dangerous view on the part of Congress that even proper pronouncements of the Court are entitled to less respect.

\section{CONCLUSION}

The risks of constitutional quibbling have been recognized for more than a century. In 1883, Justice Harlan complained about the Supreme Court proceeding "upon grounds entirely too narrow and artificial [, sacrificing] the substance and spirit of the ... alnendments of the Constitution ... by a subtle and ingenious verbal criticisn1."107 Around the turn of the century, Dean Roscoe Pound asserted that the laissezfaire judiciary was at grave risk of being cut off from the populace. $\mathrm{He}$ stated that the Court, which once stood as a protection to the individual from the Crown and the State, now "really stands between the public and what the public needs and desires, and protects mdividuals who need no protection agamst society which does need it."108 Today, many of these same objections are being directed at the Court: critics coniplain that the Court's decisions are "needlessly cramped" im order to accomplish other

H9008 (daily ed. Oct. 5, 1990) (statement of Rep. Harris) (proposing Racial Justice Act to overrule McClesky v. Kemp, 481 U.S. 279 (1987)); S. 1970, 101st Cong., 2d Sess. (1990) (Biden Bill), 136 CONG. REC. S6873, S6875 (daily ed. May 24, 1990) (statement of Sen. Biden) (bill proposed to overrule Stanford v. Kentucky, 492 U.S. 361 (1989), and Penry v. Lynaugh, 492 U.S. 302 (1989), cases permitting the imposition of the death penalty on persons under age 16 or suffering from mental retardation); S. 148, 102d Cong., 1st Sess. (1991), 137 CONG. REc. S579-01 (1991) (DerrickHughes amendments to the Omnibus Crime Control Act of 1990) (proposed to overrule McKellar v. Butler, 110 S. Ct. 1212 (1990), and Sawyer v. Smith, 110 S. Ct. 2822 (1990), cases barring courts from applying newly articulated legal principles retroactively to reverse death sentences that became final prior to the ruling).

106. Compare note 79 supra with 11 cases overruled or modified by Congress between 1970 and 1980: Citizen Publishing Co. v. United States, 394 U.S. 131 (1969), overruled by Pub. L. No. 91-353, $\S 5$, 84 Stat. 467 (1970); Alderman v. United States, 394 U.S. 165 (1969), modified by Pub. L. No. 91-452, § 702, 84 Stat. 935 (1970); Ryan Stevedoring Co. v. Pan-Atlantic S.S. Corp., 350 U.S. 124 (1956), overruled by Pub. L. No. 92-576, § 18(a), 86 Stat. 1263 (1972); Bunte Bros. v. FTC, 312 U.S. 349 (1941), overruled by Pub. L. No. 93-637, § 201(a), 88 Stat. 2193 (1975); Administrator, FAA v. Robertson, 422 U.S. 255 (1975), overruled by Pub. L. No. 94-409, § 5(b), 90 Stat. 1247 (1976); Alyeska Pipeline Serv. Co. v. Wilderness Soc'y, 421 U.S. 240 (1975), modified in part by Pub. L. No. 94-559 § 2, 90 Stat. 2641 (1976); Wingo v. Wedding, 418 U.S. 461 (1974), overrulec by Pub. L. No. 94-577, § 1, 90 Stat. 2729 (1976); Ex parte Peru, 318 U.S. 578 (1943), overruled by Pub. L. No. 94 583, § 4(a), 90 Stat. 2892 (1976); General Elec. Co. v. Gilbert, 429 U.S. 125 (1976), overruled by Pub. L. No. 95-555, § 1, 92 Stat. 2076 (1978); District of Columbia v. Carter, 409 U.S. 418 (1973) overruled by Pub. L. No. 96-170, § 1, 93 Stat. 1284 (1980); Zurcher v. Stanford Daily, 436 U.S. 547 (1978), modified by Pub. L. No. 96-440, § 101, 94 Stat. 1879 (1980).

107. The Civil Rights Cases, 109 U.S. 3, 26 (1883) (Harlan, J., dissenting).

108. Pound, Common Law and Legislation, 21 HARv. L. REv. 383, 403 (1908). 
policy goals. ${ }^{109}$

The perception of activism may do as much harm to the institution of the Supreme Court as would activism itself. Moreover, the perception is destructive to the relationship between the Court and Congress, and ultimately, is likely to produce only the opposite policy result from that sought by litigants who enlist the Court's assistance. The Civil Rights Act of 1990, then, represents more than an important piece of civil rights legislation: it is a portent to all of us who place special value on the working relationship between the Congress and the Court.

109. Fischer, Patterson v. McLean Credit Union: A Needlessly Cramped Interpretation of 1981?, 55 EDUC. L. REP. (West) 819 (1989). 